\title{
Guaranteed Employment or Guaranteed Income?
}

\section{Martin Ravallion}

\begin{abstract}
The paper critically reviews the arguments for and against both employment guarantees and income guarantees when viewed as rights-based policy instruments for poverty reduction in a developing economy, with special reference to India. Evidence on India's National Rural Employment Guarantee Act does not suggest that the potential for either providing work when needed or reducing current poverty is being realized, despite pro-poor targeting. Instead, work is often rationed by local leaders in poor areas, and the poverty impact is small when all the costs are considered. Decentralized implementation of the right-to-work poses serious challenges in poor places. The option of income support using cash transfers also has both pros and cons. Widely-used methods for finely targeting cash transfers tend to miss many poor people, and discourage those reached from earning extra income. Yet it cannot be presumed that switching to a universal basic income will reduce poverty more than workfare or finely-targeted transfers; that is an empirical question and the answer will undoubtedly vary across settings, belying the generalizations often heard from advocates. Nonetheless, more incentive-neutral, universal and/or state-contingent transfer schemes merit consideration in settings in which existing public spending is skewed against poor people and/ or there is scope for raising taxes on the rich.
\end{abstract}

Keywords: Poverty, right to work, workfare, targeting, transfers, universal basic income

JEL: H53, I38

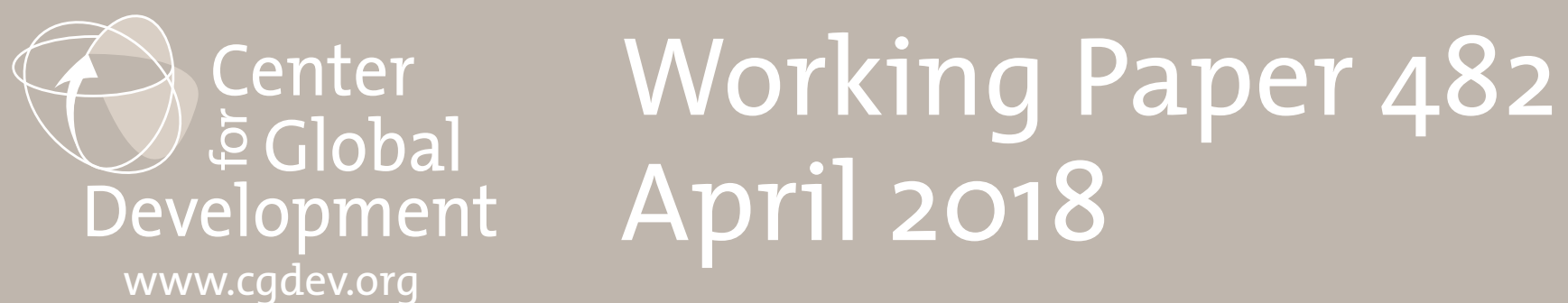




\title{
Guaranteed Employment or Guaranteed Income?
}

\author{
Martin Ravallion \\ Department of Economics, Georgetown University
}

Martin Ravallion, 2018. “Guaranteed Employment or Guaranteed Income?” CGD Working Paper 482. Washington, DC: Center for Global Development. https://www. cgdev.org/publication/guaranteed-employment-or-guaranteed-income

Center for Global Development 2055 L Street NW Washington, DC 20036

202.416.4000

(f) 202.416 .4050

www.cgdev.org
The Center for Global Development is an independent, nonprofit policy research organization dedicated to reducing global poverty and inequality and to making globalization work for the poor. Use and dissemination of this Working Paper is encouraged; however, reproduced copies may not be used for commercial purposes. Further usage is permitted under the terms of the Creative Commons License.

The views expressed in CGD Working Papers are those of the authors and should not be attributed to the board of directors, funders of the Center for Global Development, or the authors' respective organizations. 


\section{Contents}

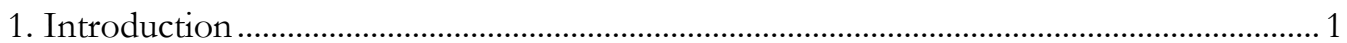

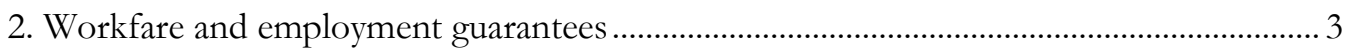

3. Constraints on realizing an employment guarantee .............................................................. 9

4. Cash transfers as an alternative antipoverty instrument .....................................................14

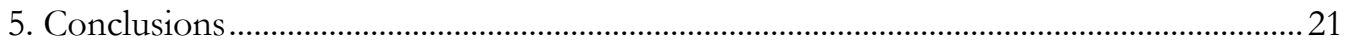

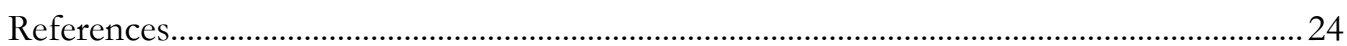

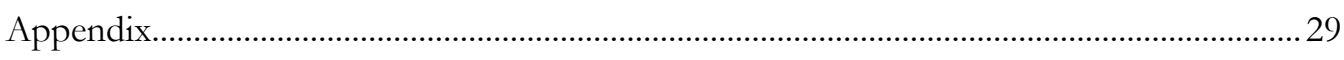

Endogenous rationing in an employment guarantee scheme.............................................2

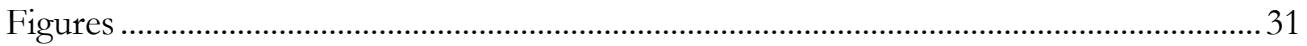




\section{Introduction}

It is often hoped that creating new legal rights for things that matter to poor people will help reduce poverty. ${ }^{1}$ Prominent rights-based social policies aim to either guarantee employment — whereby anyone who wants a job at a stipulated wage rate can get it—or to guarantee income. The employment guarantee is generally implemented by "workfare" while the income guarantee is implemented using cash transfers. These policies strive to assure the "right to work" (RTW) and "right to income" (RTI) (respectively). ${ }^{2}$ But will these rights be assured in practice? The same factors that made some people poor in the first place may well operate to undermine attempts to expand their effective rights.

This paper critically reviews the case for these rights-based policies, with special reference to developing countries, and one country in particular, India, where there has been both a longstanding effort to implement employment guarantees, and much recent interest in the idea of a universal basic income (UBI) - an untargeted cash transfer that aims to guarantee a minimum income. The discussion is relevant to other countries, but India will be the main setting considered here and main source of evidence. The paper does not advocate any specific policy, but rather tries to contribute to a better understanding of the economics underlying the policy debates.

A longstanding concern with rights-based approaches is that any policy can be justified, with no basis for setting trade-offs. ${ }^{3}$ Advocates of these approaches often argue that more should be spent on social protection, though they are not always clear on how this is to be financed. And at any given level of spending, we need to decide how to allocate it by type of program. The paper aims to judge the choice by each policy's efficacy in securing what is surely the more fundamental right, freedom from poverty. However, the paper takes a broad, welfarecentric, view of what "poverty" means. Nominal income is clearly not the only relevant variable. For example, prices clearly matter to welfare. By the same principle, one can be legitimately concerned about welfare costs such as stigma and risk aversion. A broader concept of economic welfare is needed in thinking about impacts on poverty. ${ }^{4}$

One must also make clear at the outset how literally one is to take a rights perspective. As normally understood, "rights" are obligations on the state to be fulfilled by all people within the relevant domain, such as a nation; a "right" is not something one only attains "on average." But this may be too limiting in evaluative practice; it is not useful to say that a

\footnotetext{
${ }^{1}$ Rights-based ideas about distributive justice have had a long history (Fleischacker, 2004). In the context of poverty reduction see the discussion in Ravallion (2016a, Part 1).

${ }^{2}$ The RTW is Article 6 of the International Covenant on Economic, Social and Cultural Rights; see UN (2006). RTW often heads a list of "economic rights"; see for example, Myers-Lipton (2015). RTI is close in spirit to Article 11 of the International Covenant, which requires that everyone has an adequate standard of living. Note that RTW should not be confused with "right-to-work laws" in the US, which have different aims.

${ }^{3}$ This type of complaint about rights-based approaches was heard from the earliest times in economic thinking, in writings spanning (inter alia) Jeremy Bentham and Karl Marx (Fleischacker, 2004).

${ }^{4}$ For a fuller discussion of this point see Ravallion (2016a, Chapter 3).
} 
antipoverty policy fails because some poverty remains. The key question is which policy has greater promise in reducing poverty, acknowledging that this is to be measured by an average value, such as the count of those whose right to be free from poverty is met. ${ }^{5}$

Demanding the "right to work" for very poor people, rather than a "right to income," may seem an odd idea. One usually thinks of "rights" as applying to things that have intrinsic value. ${ }^{6}$ While that holds for some types of work-jobs that have clear social value and garner public respect-it is not at all obvious for the sort of work typically done in laborintensive public works projects in developing countries. While some degree of job satisfaction cannot be ruled out, it would seem more plausible that unskilled manual work is something most poor people in rural India mainly value instrumentally, as a means to a higher income, and what this allows. (Indeed, "right to leisure" might make more sense and not just in poor places. ${ }^{7}$ ) In this setting, we mainly care about RTW policies as instruments for securing freedom from poverty. ${ }^{8}$ That may still imply a strong case for workfare. In a developing economy, the "self-targeting" feature is attractive, and could, in principle, be important enough to make this option cost effective against poverty (Ravallion, 1991; Besley and Coate, 1992). So too is the insurance feature of an employment guarantee, in settings in which credit and risk markets are far from perfect. It is ultimately an empirical question whether these potential advantages of RTW policies can make them the preferred option.

In contrast to RTW, it might seem self-evident that an income guarantee is good for reducing income poverty. But that too is far from obvious, especially when one considers incentives. There are two distinct ways of guaranteeing a minimum income, with very different rationales, information requirements and incentive effects. In the first, one imagines a set of transfers that fills all the poverty gaps, bringing everyone up to the poverty line. This is called (somewhat euphemistically) "perfect targeting." This is "needs-based" rather than rights-based. ${ }^{9}$ The second is a UBI, providing transfers set at essentially the same level for all, with little or no targeting. This is generally motivated as rights-based. Between these extremes, transfers can be targeted to poor people based on observable proxies.

Inevitably, mistakes occur in targeting. As is well-recognized in the literature, the mistakes are either exclusion errors—leaving out some poor people_-or inclusion errors_including some non-poor people. The UBI is in part a response to the (commonly-heard) complaints about the under-coverage of poor people in imperfectly targeted cash-transfer schemes. The

\footnotetext{
${ }^{5}$ Elsewhere, Ravallion (2016b) has argued that this "counting approach" does not fully reflect concerns about whether no one is "left behind," which requires that we focus on the consumption floor-the lowest level of living. While this is an important (and neglected) parameter, it is clearly not a sufficient statistic.

${ }^{6}$ Some RTW advocates do include ancillary rights (beyond a job itself), such as safety at work and freedom to unionize, that are likely to have value in themselves.

${ }^{7}$ For example, Ravallion (2017b) argues for including an allowance for leisure as a basic need in poverty measurement for the US, and provides illustrative calculations.

${ }^{8}$ Though (again) not only in that setting; as recent advocates of an employment guarantee scheme for the US put it, "A job guarantee means fewer poor Americans" (Paul et al., 2017).

${ }_{9}$ This distinction is made by advocates of the rights-based approach such as Gatenio Gabel (2016).
} 
rights perspective naturally attaches a high penalty to such exclusion errors. Hence advocates of RTI may come to favor UBI over targeted transfers that also aim to assure a minimum income, but fall short in practice. The inclusiveness of UBI also addresses concerns about the social stigma of targeting. Against this view, critics of UBI complain that the inclusion errors will be high. They claim that there are cheaper ways to reduce poverty. Budgetary pressures have led to a focus on reducing inclusion errors.

In discussing these policy issues, the paper emphasizes the constraints that tend to come with implementation in a developing country. The information available to policy makers is a key constraint; policy makers in poorer countries tend to know less about the economic circumstances of people, which naturally constrains efforts at targeting. An attraction of both the workfare and UBI policies discussed here is their minimal information requirements. Even if policy makers are well-informed, the information available to poor people can be a further constraint. Social exclusion often comes with weak connectivity to relevant sources of knowledge. ${ }^{10}$ There is evidence of significant social frictions to knowledge diffusion in rural India, such that poor people tend to be poorly informed about their rights in accessing a major anti-poverty program (Alik-Lagrange and Ravallion, 2016).

There are other constraints. Incentive constraints are important, and often emphasized by economists, though possibly not as important as some critics of antipoverty policies make out. There are costs that policy makers should consider, including any foregone earnings for participants and stigma or other welfare-losses. There are also limits to the capabilities of public administrators, associated with the generally poor infrastructure in developing countries. The reliance on local implementation is another common feature of developing countries. When we take the RTW idea to village India, say, it may well be in tension with the interests of local leaders for whom the assignment of public benefits is an important source of power and wealth. Whether the desired rights are attainable in practice is an open question, and the answer may vary between places and over time.

The following section discusses the arguments for and against using workfare to implement RTW. A key issue is whether it is feasible in practice to guarantee employment; Section 3 takes up that issue. Section 4 discusses the arguments for and against the option of direct cash transfers for assuring RTI. Section 5 concludes.

\section{Workfare and employment guarantees}

The idea of using workfare to help implement RTW has surfaced often in the history of social policy. For example, in the last few years of his life, Dr. Martin Luther King Jr. turned his attention from civil rights to poverty in America, where he saw high unemployment among poor families. King's response was that "We need an Economic Bill of Rights. This would guarantee a job to all people who want work and are able to work" (quoted by Myers-

\footnotetext{
10 The existence of knowledge constraints on access to public support has long been seen as a defining characteristic of "social exclusion" (Silver, 1994). Also see the discussions in Narayan et al. (2009), World Bank (2011) and Mansuri and Rao (2012).
} 
Lipton, 2015, p. xv). This was clearly an instrumental case for RTW, in which ending poverty was the overarching goal. ${ }^{11}$ That also appears to have been true of earlier (pre-King) proposals by Presidents Franklin D. Roosevelt (FDR) and Harry Truman, and later discussions around the Humphrey-Hawkins Full Employment Act (influenced by King's proposals) passed under President Jimmy Carter (Myers-Lipton, 2015, Chapter 1). The idea of a Federal Jobs Guarantee has re-surfaced recently in the US (Paul et al., 2017).

RTW has also been influential in India, where the idea took the form of "Employment Guarantee Schemes." The first of these, the Maharashtra Employment Guarantee Scheme (MEGS), started in 1973 in response to the threat of famine. The idea was scaled up to the national level in 2005 in the form of the Mahatma Gandhi National Rural Employment Guarantee Act (NREGA for short), which is clearly the largest workfare scheme in the world. NREGA promises 100 days of work per household per year, on demand, to all adults willing to supply unskilled manual labor to labor-intensive public works projects. The projects are mostly for water conservation/harvesting, drought protection, irrigation, roads and sanitation. The work is to be paid at the statutory minimum wage rate notified for the program, and workers are to be paid within 15 days of doing the work. If the work demanded cannot be provided by the local authorities then an unemployment allowance is to be paid by the state government.

Some assessments of such workfare programs have been very negative. For example, the author of a popular book proposing a UBI in preference to workfare writes that: "We can get rid of the whole bureaucratic rigmarole designed to force assistance recipients into lowproductivity jobs at any cost...” (Bregman, 2017, p.43). ${ }^{12}$ But are such negative assessments warranted? The following discussion reviews a number of arguments that can be made on the potential benefits, as well as the costs.

Arguments in favor: Unemployment in poor families has long been an important motivation for these policies. In a minimal sense, RTW prevails when anyone who wants work can get it. This holds in a competitive labor market, as wages adjust to clear the market. Demands for a RTW thus stem in part from (involuntary) unemployment, which may take the form of underemployment - too little work. However, this "minimal sense" does not fully capture the aims of RTW policies. Full employment can co-exist with poverty, since (depending on the setting) the market-clearing wage rate may be deemed unacceptably low. It can help to also set a minimum wage rate for the work provided, and this is common in practice. ${ }^{13}$

\footnotetext{
${ }^{11}$ For example, Myers-Lipton (2015, p.6) writes that Dr King’s proposal “....would provide poor people of all races the money necessary to pay for housing, food, transportation and health care."

12 Also see the comments in Standing (2005) and Murray (2016).

${ }^{13}$ RTW advocates sometimes add qualifiers on the type of work and working conditions, beyond requiring that all those who want a job have one at some stipulated wage rate. For example, India's National Rural Employment Guarantee Act also stipulates facilities on worksites (including drinking water and a crèche).
} 
RTW implemented through workfare can then have general equilibrium effects in supporting a floor to the wage rates for labor generally, including in sectors of the economy where work is not in fact guaranteed (Ravallion, 1990). Indeed, India's various employment guarantees can be thought of as means of implementing a minimum wage rate in settings in which this is not otherwise enforceable. As long as work is available when wanted, and labor markets are reasonably competitive, the workfare wage provides a floor to all wages. There is some evidence that states of India where NREGA has worked better (such as in providing work on demand) have seen wage gains (Imbert and Papp, 2015).

There is also evidence that improving NREGA operations can lead to higher benefits to participating workers, at least in states where the scheme already works reasonably well, such as Andhra Pradesh (AP). ${ }^{14}$ Muralidharan et al. (2018) found that the use of biometric "smartcards," to facilitate NREGA payments to workers in AP, increased their earnings, and the benefits also spilled over in the form of higher wages for non-NREGA workers. In a state such as Bihar, where the scheme is not thought to be working as well, the evidence is more mixed. Ravallion et al. (2015) found that a randomized information intervention at village level in Bihar led to higher NREGA wages for illiterate participating workers, but not for other workers, and there was little sign of other gains such as in access to NREGA jobs on demand. Similarly, in a large field-experiment in Bihar that improving administrative processes for NREGA, Banerjee et al. (2016) found that corruption was reduced but there was little increase in the wages and employment of workers. (The discussion will return to this study.)

While an employment guarantee combined with a minimum wage rate can help reduce poverty, it cannot reasonably be expected to eliminate it. There is no in-built mechanism to assure that the gain in labor earnings suffices to meet the deficit between the poverty line and other income sources for all participants. That might be assured on average (say) but not universally given that most of the relevant variables are idiosyncratic, including the capacity for work itself. This points to the desirability of complementary transfer policies, as discussed further in Section 4.

One argument that is sometimes made in support of workfare is that taxpayers and/or donors are more likely to support transfers to poor people if the latter do something costly in return. And non-poor people have long argued that work is something highly desirable for poor people to do. Some people believe in the moral superiority of toil, no matter what the result; by this view, you become a better person by working hard. Yet, against this view, taxpayers would not presumably be as supportive if they found out that the work was wasteful, and that there are more cost-effective ways of delivering help to poor people. Additionally, political economy arguments can point in the opposite direction-supporting greater universality than workfare provides (De Donder and Hindriks, 1998; Gelbach and Pritchett, 2000). This suggests that funding is likely to be less generous for more finely

\footnotetext{
${ }^{14}$ A good measure of state-level performance of NREGA is the rationing rate- the share of rural households who wanted work on the scheme but did not get it (Dutta et al., 2012). The rationing rate in AP in 2010 was 25 percent as compared to 44 percent nationally. By contrast, the rationing rate in Bihar was 79 percent.
} 
targeted programs. There is evidence from cross-country comparisons suggesting that universal provision yields broader support for fighting poverty (Korpi and Palme, 1998).

Workfare is an example of a class of policies that apply behavioral conditions for participation. These are not just motivated by current poverty reduction, but also hope to promote future poverty reduction. In the case of workfare, that condition is the work requirement. Advocates argue that this will provide skills and work habits that help participants in the future, and create assets that benefit poor areas over time. Another example of this class of policies is the Conditional Cash Transfer (CCT), which requires that the children of recipients attend school and (in some cases) comply with health-care requirements. ${ }^{15}$

The salient difference between a CCT and workfare is in the nature of the conditions. In workfare, the cost of compliance with the conditions tends to rise with income from other sources, which yields the classic "self-targeting" feature (Ravallion, 1991). As long as the workfare wage rate is not too high, the non-poor will not seek relief and participants will have an incentive to take up other work when it becomes available. Screening is achieved without explicit targeting. This has long been an important reason for imposing work requirements in settings with limited information about who is in need. By contrast, the cost of compliance with the conditions in a typical CCT probably falls as income rises; it is more likely to be the children of poor families who are not already in school. Given that a CCT is unlikely to have a self-targeting feature, these schemes invariably come with a targeting mechanism, which usually relies on observable proxies for household income.

There are other economic arguments for using workfare to implement RTW. This can provide insurance in settings in which risk markets are imperfect or non-existent. A shock induces participation, which falls in the recovery period. The empirical relationship between rainfall and participation in the MEGS is suggestive of this insurance function, at least in the period in which job guarantee appears to have been honored (Ravallion et al., 1993). However, there is not much evidence on the insurance benefits from NREGA.

In principle, a workfare scheme can also directly serve longer-term development goals by generating assets that could improve the wealth distribution, or shift production functions to permit higher returns to existing assets. (The assets could be of direct benefit to poor people, or of indirect benefit, such as through the revenue implications of using the scheme to produce taxable gains to non-poor people.) However, in practice, workfare schemes in India and elsewhere have primarily been seen as short-term palliatives against poverty. There is a trade-off here; durable asset creation in workfare tends to make the program less labor intensive, with lower impact on current poverty. ${ }^{16}$

${ }^{15}$ CCTs have emerged in a number of developing countries, following early examples such as the Food-forEducation (FFE) program in Bangladesh and the PROGRESA program (renamed Oportunidades and most recently Prospera) in Mexico. Fiszbein and Schady (2010) and Ravallion (2017a) review the literature.

${ }^{16}$ For further discussion of this trade off and its implications see Ravallion (1999). 
It would be fair to say that asset creation and/or productivity enhancement is rarely prominent in the policy rationales for these schemes in India. While there is not much solid evidence on the extent of asset creation under NREGA, it is reasonably clear that the assets created under NREGA do have some value. One often hears anecdotes that NREGA assets are mostly worthless; certainly, "NREGA roads" have a bad reputation in rural India, often washed away in each monsoon. But this is a questionable stereotype. The field work by Verma (2011) assessing water-based projects under NREGA found that some projects brought lasting positive benefits, although Verma's sample was selected in favor of the "best-performing" projects and so cannot be used to generalize about the portfolio of projects. A survey of NREGA projects in Maharashtra by Narayanan et al. (2015) found that the listed assets generally existed and that local beneficiaries were generally satisfied with the assets created based on their subjective assessments. ${ }^{17}$ Anecdotal observations have also pointed to weak local capabilities for identifying and maintaining NREGA projects and little interest among local engineers (Verma, 2011; Zimmerman, 2013). There have also been anecdotal observations that durable asset creation under NREGA has tended to favor local landowners and politicians, rather than poor households directly, who are typically landless. Certainly, many NREGA projects are on private lands, and are not local public goods; cost recovery from benefiting farmers seems to be unheard of. Nonetheless, the survey by Narayanan et al. (2015) found that many farmers with relatively small holdings reported that they benefited from the assets created.

While one can certainly point to examples of asset creation under workfare schemes, there are undoubtedly better ways available to produce assets or enhance productivity than a scheme such as NREGA. The scheme's insistence on highly labor-intensive production methods limits the cost-effectiveness and durability of the public goods created. The existence of a lower cost method for implementing a NREGA project, such as using digging machines, also creates an incentive for corruption, whereby local officials can pocket the difference in cost. The deeper policy rationale still rests in no small measure on the selftargeting ability of the work requirement and the ability to guarantee work when needed.

Arguments against. These potential benefits must be balanced against the costs generated by the work requirement. There are administrative costs, including supervision on worksites and any non-labor inputs. These costs are more visible than others that are no less important for a complete evaluation. While workfare participants may well be underemployed otherwise, they will rarely be idle, especially if poor, as their survival may then be in jeopardy. Poor households can be expected to behave in ways that attenuate forgone income, such as through the intra-household allocation of work, as shown by Datt and Ravallion (1994) for Maharashtra. However, there will typically be some forgone income for participants even when there is widespread underemployment. Dutta et al. (2014) find that workers on NREGA in Bihar had to give up work days equivalent to 40-45 percent of the total NREGA

17 Though here too the sampling was not representative, but instead Narayanan et al. picked the scheme's best performing block within each district. Results from a representative sample would probably not look as good. 
employment received. ${ }^{18}$ There are also costs of supervising the labor and providing any materials needed. The costs will undoubtedly vary from one setting or time to another, with implications for the policy choice and program design (Ravallion, 1999).

In an early assessment, Ravallion and Datt (1995) found that, once one takes account of all the costs involved, the labor earnings from the original Maharashtra scheme are unlikely to have had a higher impact on current poverty than a UBI. Twenty years later, the same conclusion was reached by Murgai et al. (2016) who found that NREGA in Bihar does not have a higher poverty impact than a revenue-neutral UBI. The potential of NREGA is great; Dutta et al. (2014) estimate that if the scheme worked as its designers intended then it would reduce the rural poverty rate in Bihar by at least 14 percentage points (from 50 percent to 36 percent). In reality, however, the impact was around a 1 percent point drop in the poverty rate-about what a UBI could do with the same budget. Both these studies for India found that the self-targeting feature worked well. The poor performance stemmed instead from the failure to assure that everyone who wanted work could get it, and be paid in a timely way, and the costs incurred by both recipients and the government in supervision and implementation (including corruption). Section 3 looks more closely at how rationing arises.

These studies have not even considered all the welfare costs involved. To understand this gap in past literature we need to go back to a key theoretical paper on the policy choice between workfare and transfers, namely Besley and Coate (1992). In their model, workfare permits screening of the poor from the nonpoor, given imperfect information on abilities. Yet the Besley-Coate analysis has two features that are inconsistent with the arguments made in favor of workfare schemes in poor rural economies. Those arguments have emphasized the existence of higher involuntary underemployment among the poor and the fact that the type of work provided gives disutility. ${ }^{19}$ Besley and Coate assume instead that there is full employment and that the policy maker attaches no welfare loss to the type of work done. While past empirical research on workfare programs in developing countries has allowed for unemployment, the work itself has not been seen to entail any welfare loss to participants. ${ }^{20}$

Having a good and worthwhile job no doubt adds to one's satisfaction with life, but that is not as a rule the type of work provided in workfare schemes in poor countries. That work is typically, and deliberately, unpleasant. And work is typically done. It can be granted that there are exceptions, such as the "ghost workers" who are signed up for wages but do not work. But this is clearly not the norm. In the case of India's NREGA, the work provided is monotonous manual labor, often toiling for long hours in the open sun. Of course, some people are not physically capable of such work. However, even among those who are, very

\footnotetext{
18 Other evidence on forgone incomes in workfare programs can be found in Datt and Ravallion (1994) (for Maharashtra India) and Jalan and Ravallion (2003) and Ravallion et al. (2005) (both for Argentina).

${ }^{19}$ In keeping with the BC model, unemployment is assumed to generally take the form of underemployment (too little work), rather than full unemployment.

${ }^{20}$ Examples include Ravallion and Datt (1995), Gaiha (1997), Jha et al. (2009, 2013), Ravi and Engler (2015) and Murgai et al. (2016).
} 
few are likely to enjoy this work, which is clearly part of the reason why relatively well-off people rarely turn up at worksites (even aside from their higher opportunity costs of time).

Alik-Lagrange and Ravallion (2018) have generalized the theoretical model of Besley and Coate to allow for both unemployment and a welfare loss associated with the work requirement. ${ }^{21}$ With full-employment, whether or not the policy maker cares about the welfare loss implied by the work requirement does not fundamentally alter the Besley-Coate conditions for the workfare program to be cost-effective, although internalizing at least part of the welfare loss increases the length of the work requirement and the transfers needed for poverty alleviation. However, all this changes when there is unemployment. A workfare evaluation should internalize the welfare loss implied by the type of work observed when poor participants are more often unemployed than richer ones in the absence of the scheme.

Taking account of the welfare loss from the type of work done can switch the costeffectiveness ranking in favor of a UBI, as Alik-Lagrange and Ravallion demonstrate for NREGA. Theoretically, there are two opposing effects of allowing for a welfare loss from the work. For any given participant, we will tend to over-estimate the benefits of the program by ignoring a welfare cost of doing the kind of work that NREGA provides. However, ignoring any welfare cost of doing casual manual work can also lead one to understate how well targeted such a program is to poor people, who will be even poorer (in terms of welfare) than their consumption suggests.

Using survey data for Bihar, Alik-Lagrange and Ravallion find that, over a plausible range of parameter values, the welfare losses from the work requirement tend to dominate the gains from better targeting performance. The scheme reaches even poorer people, but it does less to raise their welfare because participating requires effort. In the standard evaluation method in which the evaluator ignores any welfare loss from the type of work offered, the wage earnings from the scheme have about the same impact on current poverty as a UBI in which everyone receives the same amount whether poor or not. This changes if the evaluator internalizes some welfare losses associated with the type of work offered. Then a UBI clearly dominates workfare.

It appears then that NREGA would need to generate sizable indirect benefits to participating workers (such as through the assets created), and those future benefits would need to be valued sufficiently highly, before NREGA dominates a revenue-neutral UBI.

\section{Constraints on realizing an employment guarantee}

Many of these potential benefits from workfare require that people can get this work when they need it. The guarantee of work at a stipulated wage rate can be interpreted as a means of

\footnotetext{
${ }^{21}$ Note that the welfare loss referred to here is relative to an unconditional transfer. When an unemployed worker gets some extra work there is an income and utility gain relative to the prior (pre-intervention) position, by bringing the worker closer to her unrationed optimum. But that is not the relevant counterfactual here, which is the (revenue-neutral) transfer equivalent that does not come with conditions attached.
} 
implementing a "living wage" as a labor-market equilibrium in settings in which that is not enforceable as a legal mandate. Then the general equilibrium effects could be large. The guarantee also promises much needed insurance benefits to poor families. But all this begs a key question: Is the guarantee attainable in poor areas?

The administrative records on NREGA indicate virtually no un-met demand for work on the scheme. ${ }^{22}$ This is not believable. What is called "demand for work" in the administrative data is unlikely to reflect the true demand since state and local governments have neither the means not the incentive to identify and report un-met demand. (One reason being that this implies they should pay unemployment allowances.)

A better measure of demand for work is obtained by asking people directly, in the privacy of their homes and independently of the scheme. Suitable data for this purpose can be found in the $66^{\text {th }}$ Round of India's National Sample Survey (NSS) for 2009-10. This round included questions on participation and demand for work in NREGA that allow one to estimate demand and rationing rates across states. This reveals extensive rationing.

In some states, NREGA appears to conform fairly closely to its designers' intentions, and in those states there may well be larger impacts on wages, and larger insurance benefits. ${ }^{23}$ But that is not the norm in much of India. Using the NSS, Dutta et al. $(2012,2014)$ find evidence of extensive rationing, as determined by asking survey respondents if they wanted work on NREGA but did not get it. Nationally, Dutta et al. find that 44 percent of those who wanted NREGA work did not get it. This was confirmed in a more recent independent survey by the National Council of Applied Economic Research (NCAER), which found even greater rationing than suggested by the NSS data (Desai et al., 2015).

The existence of this rationing was not news to those who had studied these schemes in the past. For the original Maharashtra scheme, Ravallion et al. (1993) provide an econometric model of the relationship between monthly employment on MEGS and rainfall, and find a large reduction in employment after a doubling in the MEGS wage rate. This is suggestive that the wage hike led to rationing, which appears to have been mainly achieved by selective opening and closing of worksites.

Another salient observation about NREGA is that the incidence of rationing tends to be greater in poorer states of India, where the scheme is presumably needed the most. This pattern can be seen in Figure 1, which plots the incidence of rationing (as a proportion of rural households) against the official poverty rate. The share of the rural households rationed ranges from an average of about 10 percent in the least poor states to around one-in-three in the poorest states. ${ }^{24}$ There is a variance at any given poverty rate; for example, with about

\footnotetext{
22 According to the official Government of India website for MGNREGA (http: \\nrega.nic.in), 53 million households in India demanded work in 2009/10, and 99.4 percent were provided work.

${ }^{23}$ As noted, the findings of Imbert and Papp (2015) suggest that the scheme has had more impact on casual wages in states with more effective implementation.

${ }^{24}$ Expressing the rationing as a percent of those wanting work gives higher numbers of course.
} 
the same poverty rate, Bihar has more rationing than Chhattisgarh. But the tendency for more rationing in poorer states is evident.

A further point of interest is revealed in Figure 2, which plots the NREGA participation rate (share of the state's population of rural households who participate) against demand for NREGA (share of the state-specific population of rural households who want work, some of whom got it while some did not). The scheme only comes into action (in expectation) when demand for work exceeds 17 percent of rural households (with a standard error of 3 percent). Thus, while the average participation rate is 0.56 , the marginal rate is substantially higher; the regression coefficient is 0.91 (with a robust standard error of 0.09). Rationing appears to be less of a problem at the margin.

The rationing rules found in practice need not work against the interests of poor people. Indeed, there is some evidence that certain groups (such as defined by caste and landlessness) that are associated with above average poverty rates tend to be favored in the local rationing process (Drèze and Khera, 2009; Dutta et al., 2014). Those with the more typical profile of India's rural poor are less likely to be turned away. Possibly local officials strived for "pro-poor" targeting so as to help reduce poverty, although that is not the only explanation as we will see soon. The key point for now is that RTW is not being attained in general.

How might this rationing arise? Inadequate funding by the central government is an obvious reason. If the center fixes both the wage rate and the overall budget and the latter is inadequate then rationing is likely. This can also take the form of delays to wage payments, which have been reported in the media. ${ }^{25}$ This is plainly inconsistent with the objectives of the scheme- to provide NREGA work on demand and pay wages in a timely way.

Here the focus will be on explanations for local-level rationing when the center is willing to guarantee RTW. The first explanation relates to local costs of implementation using workfare, while the second relates to local corruption. Both also suggest how rationing might be reduced. The discussion is intuitive; a more formal exposition of the economics can be found in the Appendix.

Administrative costs with decentralized implementation: Implementation of national workfare programs is often heavily decentralized. This can be hard to avoid in practice and is seen to foster local-level participation in the choices about what work gets done, with the presumption that this will make for better projects. But this mode of delivery also imposes costs on local implementing agents. Some degree of cost-sharing between the central and local governments is considered desirable for incentive reasons. The center covers a large share of the cost of NREGA, but there are still local costs and these are not always explicit, and are hidden from view in official accounts. Diverting scarce skilled labor in the local-

${ }^{25}$ For example, in 2018 civil society groups in India reported substantial delays to the payment of NREGA workers, apparently stemming from inadequate funds made available from the center (The Hindu, 2018). 
government bureaucracy from other tasks to deal with the center's "red tape" of reporting and approval requests will entail opportunity costs.

Decentralized implementation should be seen in the relevant institutional context. More systematic assessments have supported the anecdotal observations from field work that there is a chronic underinvestment in local state capacity in India, as evident in under-resourced and over-worked local bureaucracies (Dasgupta and Kapur, 2017). Also important to the functioning of the scheme at local level is the availability of "brokers" who can be trusted by local leaders to mediate between them and the various stakeholders, including workers but also local officials and landowners (Witsoe, 2012). Local leaders or their close family members often act as money lenders as well as contractors, making advance payments to workers and intervening between the delivery point (often the local post office) and the intended beneficiary.

While it is plausible that the local implementing official incurs a cost per worker employed on the scheme, it is unlikely that the official is indifferent to the amount of unmet demand for work. The local official has the option of not hiring all those who want work, but the official surely does not want to drive employment down to zero. If one is thinking about a local government in a federal system then one can imagine that the local official is either sympathetic with the objectives of the scheme, or that he or she perceives a likely (economic or political) penalty of unmet demand for work. This penalty falls to zero when there is no unmet demand for work but rises with higher unmet demand. It is plausible that the penalty rises more steeply as the excess demand rises; at very high levels of unmet demand the protests may well be vastly greater than at low levels. The local official minimizes the direct cost plus the penalty attached to rationing. Thus the official sees a trade-off between the cost of employing extra workers under the scheme and the desire to meet the demand for work.

The upshot of this argument is that local costs of implementation imply that rationing can emerge as an equilibrium outcome in a scheme such as NREGA even when the central government makes an open-ended commitment for funding a large share of the cost. Above some critical level of the local unit cost of employment, rationing emerges. However, and importantly for policy, the rationing rate (as a proportion of demand) is likely to be lower at the margin than on average, so the average rate will tend to fall as demand increases.

Reducing local administrative costs (including enhancing the capacity and productivity of local administrators) will make RTW more feasible in this type of scheme. But we must also consider the scope for corruption and the role of central efforts to fight corruption.

Corruption and the employment guarantee: The administrative challenges in implementing RTW through workfare come with scope for corruption. It is not too surprising that we often hear in the Indian press about (for example) Bihar's "millionaire Mukhiyas" (Gupta, 2013). ${ }^{26}$ Less obviously, as we will see, central governmental efforts to

26 "Mukhiya" is the local name for village leaders. 
fight corruption can have perverse effects—increasing the amount of rationing and so further undermining RTW. Deeper reforms are needed.

At first glance, corruption is probably not an intuitively obvious reason for rationing. If corrupt officials can skim off their 10 percent (say) from workfare participants then they will still have an incentive to provide work to all who want it. The model of corruption in a program like NREGA may, however, be more complex than suggested by a fixed-share rule.

One can illustrate this by augmenting the model of decentralized administration sketched above to allow for corruption (Appendix). Suppose that local official chooses the level of employment she wants to provide, given an exogenous demand for work on the scheme. There is a pecuniary benefit to the official that naturally depends on the level of employment. We can think of this as the official's cut on the wages paid. But there is a cost too facing the local official. This includes the side-payments that the official must make to cooperating agents, and the cost must factor in the risk of getting caught and the penalty. The total expected cost of corruption also rises with the number of workers employed, as this will require opening more work sites and higher payments to "ghost workers," with further side payments required to cooperating workers and officials, and higher risks of exposure. It is also likely that the expected marginal cost of corruption facing the official will rise as employment rises. The local official may have to expand the set of people he bribes beyond his own "comfort zone" of those he trusts, and even those he trusts will face greater risk of exposure at larger scale, and so require higher compensation.

The marginal cost of providing extra employment now includes the expected marginal cost of corruption as well as the local administrative cost already discussed. The ideal level of employment from the perspective of the local official equates the total marginal cost (MC) with the marginal benefit (MB), as illustrated in Figure 3. If this turns out to be less than the number who want work then rationing arises in equilibrium (Appendix).

Suppose now that the central or state government tries to clamp down on local corruption by (inter alia) imposing higher fines or jail terms, or with extra auditing/policing and/or more transparent record keeping, implying a higher probability of being caught. This can be interpreted as a shift in the expected marginal cost of corruption facing the local official. That will decrease employment and increase rationing - making RTW harder to attain as can be seen from the shift in the MC curve in Figure 3. High levels of rationing in poorer states (as in Figure 1) may well reflect central and state government efforts to clamp down on corruption in poor places.

On combining local administrative costs with corruption we can understand the ambiguity of partial reform efforts. The benefits to workers of a reform that reduces local administrative costs can evaporate when the reform also increases the expected marginal cost of corruption facing local officials. This offers an interpretation of the Banerjee et al. (2016) finding for Bihar that better administrative processes for NREGA reduced corruption but did little to increase the wages and employment of workers. The reforms in this experiment essentially combined a lower local administrative cost with a higher expected 
marginal cost of corruption facing local officials. Corruption fell but employment did not change indicating that the rationing largely remained.

There is likely to be heterogeneity in the cost of corruption facing a local official, depending on characteristics of workers. Suppose, for example, that literate and/or higher- caste workers are more likely to complain about an official's corrupt rent-seeking efforts, with implications for the probability of the official getting caught. In particular, suppose that the expected MC of corruption is higher for such workers. Then, of course, the official will tend to favor other, more acquiescent, workers in deciding how to assign employment. Thus, one can understand why Dutta et al. (2014) find that the implicit rationing rules in Bihar's NREGA tended to favor workers with the more typical profile of the poor, and we can understand this finding without believing that the officials are trying to reduce poverty.

We have seen that, with decentralized implementation of an employment guarantee scheme, rationing can emerge in equilibrium given the local costs of employing workers and the scope for corruption. The RTW need not be incentive compatible. Nonetheless, the share of demand that is rationed may well diminish as the scheme expands. The data for India are consistent with the prediction of the theoretical model that the rationing rate at the margin will be less than the average rate. By implication, the insurance and other benefits of the work guarantee will tend to emerge as the scheme expands above some point. Those benefits will also rise if local implementation costs are reduced. But combining a lower local administrative cost with anti-corruption reforms that increase the expected marginal cost of corruption need not help attain RTW.

Assuring that local agents do not have the power to ration work will require a deeper local institutional reform. "Social audits" — open village meetings fostering public disclosure of concerns - could help, backed up by credible procedures for responding to grievances (Dutta et al., 2014).

\section{Cash transfers as an alternative antipoverty instrument}

Both approaches to guaranteeing a minimum income level—perfect targeting and a UBIhave instructive histories. The Speenhamland System of 1795, introduced by the justices of Berkshire, England, guaranteed local working-class residents a basic income. ${ }^{27}$ Current wages were topped-up to assure that the income of the family reached the poverty line, with the unemployed receiving full payment. The Speenhamland System was more needs-based than rights-based. Its aim was close to that of perfect targeting.

The UBI idea also goes back to at least the $\mathrm{C}^{8} 8^{\text {th }}$. Paine (1797) argued that agricultural land was "natural property," to which every citizen had a claim, but that an efficiency case existed for its private ownership. Instead of being nationalized, Paine argued that agrarian land should be privately owned but subject to taxation—a "ground rent," the revenue from

${ }^{27}$ For further discussion of this policy see Ravallion (2016a, Chapter 1). 
which should be allocated equally to all adults in society, as all have a claim to that property. And this was not to be seen as charity but as a right.

There were a number of local-level pilot experiments with basic income in North America in the 1960s and '70s, with generally positive assessments. Indeed, President Nixon put forward a Family Assistance Plan, which would have provided a modest basic income for the U.S. (This passed the House but not the Senate. ${ }^{28}$ ) More recently, Alaska puts a share of its oil and mineral revenues into the Alaska Permanent Fund, which makes dividend payments as uniform transfers to all Alaskans (following, it seems, Paine's, 1797, advice). And Finland introduced a pilot UBI in 2016, for those receiving unemployment benefits.

While the (limited) examples of UBIs to date have been for relatively rich countries, a number of authors have argued that a UBI is no less relevant in low and middle-income countries and may well be more efficient at reducing poverty. ${ }^{29}$ There has been much recent debate in India on the UBI idea. The Ministry of Finance's Economic Surveys of 2016-17 and 2017-18 are sympathetic to the UBI idea, which prompted much debate. ${ }^{30}$ Davala et al. (2015) and Joshi (2016) also propose a UBI for India. Since a full UBI has not yet been tried in India (or anywhere for that matter, at national level), we do not have the same type of evidence as used in Sections 2 and 3 in discussing NREGA.

The UBI idea is getting a great deal of attention today, especially in the (conventional and social) media. The idea appears to be popular. An opinion poll by Dalia Research in 2015 indicates that about two-thirds of Europeans support a UBI. The popularity must depend on the details of design and context, and this does not always come out in the arguments made by supporters. ${ }^{31}$ There is a certain amount of advocacy, with weak theoretical and empirical foundations, and even some confusion. The following discussion provides a critical review of the arguments for and against a UBI, noting issues for which more research is called for.

Arguments in favor: Advocates have seen a UBI as an administratively easy way of reducing poverty and inequality, with modest distortionary effect and avoiding the social stigma often associated with targeted transfers.

Different aspects of UBI have appealed to different people. Some are keen on its simplicity, greatly reducing the "entire bureaucratic apparatus of government social workers" (Murray, 2016). ${ }^{32}$ From a public finance perspective, a UBI has been seen as a budget-neutral way of integrating social benefits and income taxation. When financed by progressive income taxes,

\footnotetext{
28 There is a good discussion in Bregman (2017, Ch.4).

${ }^{29}$ See Ravallion and Datt (1995), Bardhan (2011), Murgai et al. (2016), and Government of India (2016).

30 See GOI (2017, 2018). Contributions to the debate include Drèze (2017), Khosla (2017), and Sandefur (2017).

31 In a referendum in Switzerland in 2016, only 23 percent of those voting were in favor of a UBI. The

referendum proposal was vague (including on the benefit level), and this uncertainty clearly did not help assure broad support.

32 A similar comment is found in Bregman (2015).
} 
the UBI is equivalent to Friedman's (1962) negative income tax. Some reform proposals for existing welfare and tax systems have included a UBI. ${ }^{33}$

The "freedom" concept is key for some advocates. A sufficiently high UBI benefit level will free people to do whatever they like, including self-employment and unpaid work. ${ }^{34}$ In the vision of advocates, a UBI can provide the freedom to not work - to pursue whatever occupation one likes even if it is not especially remunerative personally. This is clearly a significant break from past employment-oriented welfare policies, including workfare.

Another break is with past family-oriented approaches to social policy. UBI proposals are for a common payment to all individuals, with implications for the distribution of power and income within households. In some settings, a UBI will enhance the bargaining power of women. (Though some observers have seen this as a bad outcome! ${ }^{35}$ ) The opposite holds in settings in which existing transfer policies are targeting women (which is now widely advocated in developing countries). This benefit too will depend on the context.

UBI advocates have not seen any serious tension between a UBI and a capitalist-market economy. Indeed (similarly to Paine, 1797), Van Parijs (1995) argues for "basic income capitalism" - combining the power of private ownership and free markets, but recognizing that this can leave too much poverty and inequality, so some minimum income must be assured for all. This is an instance of a more general motivation for social policies (on top of ethical objections to poverty and inequality), namely a desire to "save capitalism from itself" (Abramovitz, 2004, p. 22), including compensating losers from reforms.

Nor do most UBI advocates appear to see this as something that is time bound. A UBI is viewed as a long-lasting policy, and this can have benefits in supporting people's longer-term plans. The UBI is an increment to permanent income. One implication is that it is not clear how relevant past evaluations of (almost always) relatively transient cash transfer programs are to the UBI debate. Clearly a short-lived program can have very different effects on intertemporal decision making.

Arguments against. Top of the list of concerns is the cost and how it is to be financed. One cannot meaningfully assess the poverty impacts of any cash transfer program without allowing for the impacts of its method of financing, which will entail either higher taxes or less spending on something else. When transfers are financed by lower spending on other public programs, the benefits and costs of those programs must of course be considered, though that has not always been so. ${ }^{36}$ While most countries already spend on direct

\footnotetext{
33 See, for example, Atkinson and Sutherland (1989) and Browne and Immervoll (2017).

34 See, for example, Van Parijs (1995), Standing (2005) and Bregman (2015).

35 Bregman (2015, Chapter 2) tells how UBI proposals for the US were shelved in 1978 when it was found that divorce rates had risen sharply in a pilot UBI experiment (in Seattle). As it turns out, this was a data processing error, and divorce rates had not been impacted. But the belief derailed the policy.

${ }^{36}$ For example, Khosla (2017) argues that the calculations in Government of India (2016, Chapter 9) of poverty impacts in India of a potential UBI do not take proper account of the impacts of the other welfare programs that would probably be cut to make way for the UBI.
} 
interventions against poverty, they also spend on health and schooling services that are typically un-targeted but benefit poor people. Transfers will clearly look worse if introduced at the expense of (say) better quality schooling for poor people than if financed by taxes on the rich. It has been argued that a UBI diverts attention from other priorities such as health and education. For example, in the Indian context, Drèze (2017, p.2) warns of “.... real danger of UBI becoming a Trojan horse for the dismantling of hard-worn entitlements of the underprivileged." This is a serious concern. Simulations for selected countries in Europe indicate that there will be both gainers and losers among the poor from replacing existing benefits by a UBI, with the potential for a net increase in the poverty rate (Browne and Immervoll, 2017).

In thinking about UBI, it would make sense to define "income" more broadly than just cash income. A full-income concept could include imputed values for services in kind, such as publicly provided health insurance and schooling. If the shadow prices for imputation cannot be determined with adequate confidence then we will need a "dashboard" of fullincome components. ${ }^{37}$ A UBI discussion would then embrace these non-cash dimensions of welfare. The composition of the basic full-income package would then be a policy choice. That choice would be important, and it will never be easy. There are concerns about paternalism, i.e., overriding the preferences of poor people. But the key point is that noncash benefits should be factored into any characterization of what, exactly, is guaranteed.

Protestations about the cost of a UBI ring hollow without specifying what spending it replaces and how else it is financed. A key question is whether the same resources can be better spent on a UBI, even if a rather modest benefit level. In some countries, the existing welfare system might well do better than a UBI from the perspective of poverty reduction. ${ }^{38}$ Other countries - such as those relying heavily on subsidies on the consumption of normal goods such as food and fuel—could do better with a UBI. India has many subsidies that benefit the non-poor more than the poor. Bardhan (2011) and Government of India (2017, 2018) have argued that cutting these subsidies and replacing them with some form of UBI could well have greater impact on poverty. More remarkably, a UBI could well be more costeffective than India's main programs targeted to the poor. As noted in section 2, it appears that, once all the costs are factored in, a UBI would be as cost-effective against current poverty as India's employment guarantee programs (Ravallion and Datt 1995; Murgai et al. 2016; Alik-Lagrange and Ravallion, 2018).

Another common complaint about UBI and transfers in general is that (to paraphrase) they "destroy incentives to work." By this view, recipients become lazy and dependent. It can be readily agreed that high marginal tax rates (MTRs) on poor people should be avoided, though the MTR's implied by the formal rules need not hold in practice. ${ }^{39}$ Incentive effects

\footnotetext{
37 This is a similar idea to the ILO's (2012) "Social Protection Floor."

38 Examples can be found in IMF (2017) and Browne and Immervoll (2017).

${ }^{39}$ For example, China's large targeted cash transfer scheme, Dibao, has a 100 percent MTR on paper but it has been found that local implementing agents greatly reduce the MTRs in practice by smoothing the transfers in response to recipient income changes (Ravallion and Chen, 2015).
} 
at moderate MTRs may not be a serious concern, as shown by Banerjee et al. (2017). And the concerns about incentive effects are even less persuasive for a UBI since (unlike targeted transfers) nobody would be able to do anything to change how much they got. Granted, there will still be an income effect on demand for leisure that may reduce labor supply (though some supporters don't think this is a bad thing). But here too there is a risk of exaggeration. The evidence for the US reviewed in Marinescu (2018) suggests that the effect on labor supply is likely to be small; indeed, many studies suggest it is close to zero. ${ }^{40}$ With reference to the Alaska Permanent Fund, Jones and Marinescu (2017) find evidence of macroeconomic gains through higher effective demand, and little sign of employment effects.

Transfers (in various forms, including UBI) can sometimes help relax other constraints facing poor families, including uninsured risk and credit constraints, with positive implications for employment and wealth creation, including in human capital formation. These effects may well offset any income effect on demand for leisure. The evidence is mixed on this issue, with some studies finding longer-term effects of transfers consistent with relaxing credit constraints, but others finding little effect. ${ }^{41}$ There are many differences in the context, design and scale of the programs studied in this literature-differences that may well account for the lack of a consistent picture. (For example, as already noted, a oneoff or transient transfer payment is likely to have very different behavioral effects to a nearpermanent one, as in UBI proposals.) But it is notable how hard it is to find any solid evidence for adverse longer-term effects of transfers consistent with the "horror stories" of laziness and dependency among transfer recipients that one has heard so often in the media, and have been so influential.

Targeted transfers: ${ }^{42}$ Some of the evidence reviewed above may lead one to advocate transfers to poor people, but not a UBI. Critics of the UBI idea have claimed that poverty can be reduced at a much lower cost - that we don't need a UBI if poverty reduction is the goal. For example, Bregman (2017, p.43) (who advocates a UBI) claims that "the world's developing countries had it within their means to wipe out poverty years ago." A supportive footnote claims that global poverty can be eliminated for only 0.7 percent of global GDP (Bregman, 2017, pp. 274-5). Bregman calculates this by multiplying $\$ 1.25$ per person per day (a poverty line proposed in 2005 prices by Ravallion et al., 2008) by the number of poor people living below $\$ 1.25$. Another popular calculation claims to bring the cost of eliminating poverty down even further by measuring each poor person's poverty gap and adding up the implied transfers, i.e., perfect targeting. Poverty is then eliminated—or so it seems. A budget to cover the current aggregate poverty gap will almost always be much

\footnotetext{
40 Summarizing the evidence for the US, Marinescu (2018) concludes that many studies find no impact on labor supply, and for those that do find an impact it is small—among those studies, a 10 percent increase in income from unconditional cash transfers results in an average 1 percent drop in labor supply.

${ }^{41}$ Relevant studies for developing countries include Ardington et al. (2009), Chen et al. (2009), Blattman et al. (2014), Haushofer and Shapiro (2018), and Baird et al. (2018). Also see the surveys U.S. studies on incentive effects in Moffitt (1992) and Marinescu (2018).

42 There is a large literature on targeting; contributions include Besley and Kanbur (1993), Grosh (1994) and van de Walle (1998). For a recent overview, focusing on the policies, see Ravallion (2017a).
} 
smaller than the cost of a UBI, and also smaller than the cost of a uniform transfer to all of the poor. ${ }^{43}$ One widely-cited calculation gives the aggregate poverty gap for the $\$ 1.90$ a day poverty line for 2011 (anchored to the $\$ 1.25$ line for 2005) at about $\$ 70$ billion in 2015 (Chandy et al., 2016), ${ }^{44}$ which "is roughly what Americans spend on lottery tickets every year, and it is about half of what the world spends on foreign aid." (Lowrie, 2017). The implication drawn is that it is relatively easy to eliminate global poverty using transfers.

However, these popular calculations are deceptive. ${ }^{45}$ There are four main reasons. The first concerns the information constraints on targeting, which can be severe in poor countries with weak administrative capacity for data collection. Policymakers in practice have access to a limited subset of the information needed to reliably establish who is poor (as required by Bregman's calculation) or how poor they are (as required by the poverty gap calculation used by Chandy et al. and others). A common targeting method uses a proxy means test (PMT). Here a statistical model is used to calibrate a score to proxy income, based on a limited set of household characteristics in a sample survey — characteristics that can also be readily observed in the population as a whole, such as location, household size and some assets and consumer durables. Those with a sufficiently low score receive a transfer. However, prevailing methods of fine targeting using this method have often disappointed in practice. Even with a fixed budget sufficient to eliminate poverty with perfect information, optimally designed transfers as a function of the (incomplete) information that is available do not come close to eliminating poverty, as shown for several countries in Africa by Brown et al. (2017). Even with the aggregate poverty gap as the budget, three-quarters of the poverty in the Brown et al. sample for Africa would remain.

In the case of India, transfers (including through the food rationing system) are based on an assignment of ration cards- "Below Poverty Line" (BPL) cards that are provided to those deemed to be poor. As noted, a budget-neutral re-assignment of spending on NREGA in Bihar would have about the same impact on poverty if it was turned into a UBI (Murgai et al., 2016). That also turns out to be true if instead the transfers were based on the BPL cards, with everyone holding a BPL card getting the same payment (Murgai et al., 2016). The targeting of the BPL cards is not all that different to a random allocation.

Information asymmetry is also relevant, with more information available locally than at the center. This creates horizontal inequities of targeted policies. At the community level, targeting using PMT may appear opaque or almost random. People can see that equally poor families are treated differently, with some getting help and others not. The obvious

\footnotetext{
${ }^{43}$ Indeed, it can be readily shown that the poverty gap index is the ratio of the minimum cost (with perfect targeting and no incentive effects) to the maximum cost, using a UBI (Ravallion, 1994).

44 The $\$ 70$ billion is evaluated at market exchange rates rather than purchasing-power parity (PPP). This was done because the authors are imagining that the gap would be covered by foreign aid, or taxes on the global rich. When calculated at PPP the aggregate poverty gap for the same year is roughly double the $\$ 70$ billion figure.

45 The exposition of the poverty gap in Ravallion (1994) explicitly warns against this policy interpretation. Comments on the Chandy et al. (2016) post include Ozler (2017), Sandefur (2017) and Ravallion (2017c),
} 
unfairness can generate social conflict and undermine well-intentioned social policies. There can be gains from tapping into community-based information, but there are risks too, notably elite capture at local level (Mansuri and Rao 2012). ${ }^{46}$

The key point is that we should not presume that there are large gains to poor families from exploiting the information available to policy makers. And we know even less about living conditions at the individual level, as shown by Brown et al. (2018) for Africa. Intra-

household inequalities and common exposure to health risks can entail that poor individuals are spread quite widely across the distribution of household wealth, with a large share not found in observationally-poor households.

Second, when the budget is free to vary, finer targeting may well undermine public support for anti-poverty policies (Sen 1995). Political economy models have elaborated this point (De Donder and Hindriks, 1998; Gelbach and Pritchett, 2000). The poor may well end up with a larger share of a smaller pie, with theoretically ambiguous gains. However, whether this happens in practice will depend on many factors, including program design, public promotion, and the extent of income risk (such that often electorally-powerful middleincome groups face significant downside risk that the program could help address).

The third reason why the potential cost saving (relative to a UBI) from targeting may prove to be limited in practice concerns incentives. As already noted, the generalizations often heard about the adverse incentive effects of transfers ave received rather little support from research, although there is still a strong a priori case for believing that very high MTRs on poor people are a bad idea. Yet, if implemented exactly and continuously, perfect targeting implies a 100 percent MTR; if a poor family's income increases by $\$ 1$, and they remain poor, then the family's benefit falls by $\$ 1$. Once everyone realized how it works, the cost would undoubtedly rise until it is higher than the initial aggregate poverty gap.

Finally, analogously to the welfare losses from the type of work often available in workfare schemes (Section 2), targeted transfers can create a social stigma for recipients. ${ }^{47}$ This is also a welfare loss, though typically missing from the calculations of the potential cost savings from targeting.

The intermediate cases between "perfect targeting" and a UBI include state-contingent $\underline{\text { transfers, }}$ meaning that the transfer is uniform within some category of people. The states that trigger the transfers may be fixed or predictable (such as age) or adverse events (such as widowhood or unemployment). This type of state-contingent transfer scheme has been widely used in today's rich countries, including when they were poor countries. ${ }^{48}$ There is ample scope for such policies in today's developing countries. In the Indian context, Drèze

\footnotetext{
46 Alatas et al. (2012) compare community-based targeting with PMT for an Indonesian cash transfer scheme. They find that PMT does somewhat better at reaching the poor but community-based targeting better accords with local perceptions of poverty and is better accepted by local residents.

${ }^{47}$ For an overview of literature on this topic in the context of antipoverty policies see Walker (2014, Chapter 4).

48 England's Old Poor Laws dating back to the $16^{\text {th }}$ century are an example (Solar, 1995). In modern times, noncontributory old-age pensions and family allowances are often uniform.
} 
(2017) points to the desirability of universal maternity entitlements and social security pensions.

Uniform state-contingent transfers do not achieve the vision of a full citizenship income that some UBI advocates have wanted, and there will be targeting errors, but they do address some of the aforementioned concerns about both a full UBI and fine targeting. And some UBI proposals have allowed explicitly for a sensible degree of differentiation, such as by age and location. ${ }^{49}$ Indeed, strict universality could be judged to be unfair; why should children receive as much as adults? Some intrusion of a "needs" perspective into rights-based policies may well be inescapable. Yet a state-contingent basic income is nothing more than a targeted policy based on categorical poverty indicators. Then the lines between UBI and targeted assistance are more blurred than suggested by the debates among advocates.

In the not-too-distant future, new information technologies will help make direct transfers more viable by supporting validation of applicant information and lowering transaction costs, and also relieving poor people of the need to rely on exploitative brokers. India's new biometric identity card (aadhaar) is an example of this type of technology, which can reduce the scope for corruption such as through multiple payments to the same person or fictitious "ghost applicants." As the banking system becomes more developed, automated teller machines and short-messaging services through mobile phones will no doubt also reduce the costs of making direct transfers. ${ }^{50}$

\section{Conclusions}

A "right to work" policy implemented through public employment can seem an attractive option when poor people face risky environments, high unemployment rates, the reliable information for targeting is limited, and there is much useful work to do in poor areas. Realizing that potential is another matter. The self-targeting feature is plausible and consistent with the evidence. But it is far from obvious that this will be the best way to reduce poverty — taking freedom from poverty to be the overarching right—once one considers all the costs involved. These include implementation costs, pecuniary costs to the participants in the form of forgone earnings (which can exist even for underemployed workers) and the welfare loss from the work requirement relative to unconditional transfers. The paper has pointed to evidence for India suggesting that the country's Employment Guarantee Schemes have been less cost effective in reducing current poverty through the earnings gains to workers than one would expect from even untargeted transfers, as in a UBI. This calculation could switch in favor of workfare schemes if they can produce assets of value (directly or indirectly) to poor people, though the evidence is mixed on this aspect of the schemes so far in India. The Indian experience also suggests diverse performance across states of its Employment Guarantee Schemes. It is worrying that the schemes tend to

49 This is proposed by Van Parijs and Vanederborght (2017, p.9). Also see Alston (2017).

${ }^{50}$ For further discussion see Jack et al. (2013) and Gibson et al. (2014). 
work less well in poorer states, where they are probably needed more. Arguably that is not too surprising, as the same factors that make a place poor impede efforts to change.

Local rationing of the work opportunities provided by these scheme in poor areas can readily arise from the existence of (often latent) local administrative costs in implementation and from the partial means used by the center to fight local corruption. The main concern with rationing is not that it undermines pro-poor targeting; indeed, that is not implied by the model of local corruption used here, and nor is it consistent with the evidence for India. But rationing undermines the gains to poor people from the employment guarantee, including its insurance benefits. Scaling up may well help; indeed, with local administrative costs, the marginal rationing rate will tend to be lower than the average rate, and that is consistent with the cross-state evidence for India.

Anti-corruption efforts and administrative reforms from the center can have ambiguous effects on the extent to which RTW can be achieved in practice. Raising the expected marginal cost of corruption facing local officials is likely to reduce the extent to which employment is available to those who need it. Cutting local administrative costs can help, but when this is achieved within a reform that also raises the marginal cost of corruption facing local officials (such as by making record-keeping and reporting more transparent as well as easier) there may be little net gain to workers in terms of assuring their RTW.

Direct cash transfers are now a viable policy option and their use is expanding rapidly. There is much interest, and debate, about this option for India. A key question is whether the transfers should be finely targeted to observationally-poor people. The ability of a government to do so effectively will also vary from one setting to another, but in many cases the information constraint alone can entail that many poor people are not reached. Even with good information, fine targeting has costs, such as the disincentives created by high marginal tax rates. Finely targeted social policies that focus on avoiding leakage to the nonpoor rarely employ the kind of information needed to be very effective against poverty, are often based on an incomplete accounting of the costs incurred (not least by poor people), and often end up excluding many who are in real need.

A rights-based perspective points to the advantages of a UBI in poor places. While this is getting much attention these days as a social policy option in rich countries, it may well make sense-possibly more sense-in places with poor information, weak capabilities for targeting, and a high poverty rate. Financing is key of course. There are concerns that the money will come from other public spending benefiting poor people although there are clearly other options. Taxes on readily-identified rich citizens, or eligibility restrictions, may be used to implement a fiscally-viable UBI with low exclusion errors. The final outcome for poverty will of course depend on many factors, including the information available for identifying poor people and the feasible means of financing, including the scope for identifying and taxing rich people.

As this review has hopefully made clear, when you think about this policy choice, and look at the available evidence, it is very hard to come out unconditionally on either side (which is partly why it is such an interesting policy issue). Both employment and income guarantees 
have been motivated by an appeal to rights. That perspective has value, and should be taken more seriously by economists (not least because of its legal and philosophical roots).

However, it is unlikely that the policy choice can be satisfactorily resolved by an appeal to rights alone. The needs-perspective and various constraints (including budgets) will almost certainly come into play and these create heterogeneity in the conditions relevant to the success of either approach to policy. The best option will no doubt vary with the setting, including over time, defying the generalizations that one hears from advocates.

Nonetheless, policy makers should remain open to the possibility that, once all the costs and benefits to poor people are considered, the two most popular policies today-self-targeted workfare or the finely-targeted (conditional or unconditional) transfers-may well be dominated by more transparent forms of universality, including a "basic full income," possibly with some sensible differentiation. Whether one thinks of this as a "differentiated UBI" or "categorical targeting" does not matter. The key point is that, in some settings, less effort at fine targeting may well prove to be more cost-effective in assuring economic freedom from material deprivation. 


\section{References}

Abramovitz, Mimi (2004), “Saving Capitalism from Itself: Whither the Welfare State?” New England Journal of Social Policy 20(1): 21-31.

Alatas, Vivi, Abhijit Banerjee, Rema Hanna, Benjamin A. Olken and Julia Tobias (2012), "Targeting the Poor: Evidence from a Field Experiment in Indonesia," American Economic Review 102(4): 1206-40.

Alik-Lagrange, Arthur, and Martin Ravallion (2016), "Social Frictions to Knowledge Diffusion: Evidence from an Information Intervention,” NBER Working Paper 21877. , and (2018), "Workfare versus Transfers in Rural India," mimeo, Georgetown University.

Alston, Philip (2017), "Report of the Special Rapporteur on Extreme Poverty and Human Rights," Human Rights Council, United Nations General Assembly.

Ardington, Cally, Anne Case and Victoria Hosegood (2009), "Labor Supply Responses to Large Social Transfers: Longitudinal Evidence from South Africa", American Economic Journal: Applied Economics, 1(1):22-48.

Baird, Sarah, Craig McIntosh and Berk Ozler (2018), "When the Money Runs Out: Do Cash Transfers Have Sustained Effects on Human Capital Accumulation?” George Washington University, Washington DC.

Banerjee, Abhijit, Esther Duflo, Clement Imbert, Santhosh Mathew, and Rohini Pande (2016), "E-governance, Accountability, and Leakage in Public Programs: Experimental Evidence from a Financial Management Reform in India," NBER Working Papers 22803, National Bureau of Economic Research.

Banerjee, Abhijit, Rema Hanna, Gabriel Kreindler and Benjamin Olken (2017), 'Debunking the Stereotype of the Lazy Welfare Recipient: Evidence from Cash Transfer Programs Worldwide', Massachusetts Institute of Technology, Cambridge, Massachusetts.

Bardhan, Pranab (2011), "Challenges for a Minimum Social Democracy in India," Economic and Political Weekly 46(10): 39-43.

Besley, Timothy, and Stephen Coate (1992), "Workfare vs. Welfare: Incentive Arguments for Work Requirements in Poverty Alleviation Programs," American Economic Review 82(1): 249-61.

Besley, Timothy, and Ravi Kanbur (1993), "Principles of Targeting," in Michael Lipton and Jacques van der Gaag (eds), Including the Poor, Johns Hopkins University Press for the World Bank, Washington DC.

Blattman, Christopher, Nathan Fiala and Sebastian Mrtinez (2014), "Generating Skilled SelfEmployment in Developing Countries: Experimental Evidence from Uganda," Quarterly Journal of Economics 129(2): 697-752.

Brown, Caitlin, Martin Ravallion and Dominique van de Walle (2017), 'A Poor Means Test? Econometric Targeting in Africa’, NBER Working Paper 22919. and (2018), "Most of Africa's

Nutritionally-Deprived Women and Children are Not Found in Poor Households," NBER Working Paper.

Browne, James, and Herwig Immervoll (2017), "Mechanics of Replacing Benefit Systems with a Basic Income: Comparative Results from a Microsimulation Approach," Journal of Economic Inequality 15: 325-344. 
Chandy, Laurence, Lorenz Noe, and Christine Zhang (2016), “The global poverty gap is falling. Billionaires could help close it.” Blog post, Brookings Institution, January 20.

Chen, Shaohua, Ren Mu and Martin Ravallion (2009), "Are There Lasting Impacts of Aid to Poor Areas? Evidence from Rural China," Journal of Public Economics 93: 512-528.

Dasgupta, Aditya, and Devesh Kapur, 2017, “The Political Economy of Bureaucratic Effectiveness: Evidence from Local Rural Development Officials in India."

Datt, Gaurav, and Martin Ravallion (1994), "Transfer Benefits from Public-Works Employment," Economic Journal 104: 1346-1369.

Davala, Sarath, Renana Jhabvala, Soumya Mehta, and Guy Standing (2015). Basic Income: A Transformative Policy for India, London and New Delhi, Bloomsbury Academic.

De Donder, Philippe, and Jean Hindriks (1998), “The Political Economy of Targeting," Public Choice 95: 177-200.

Desai, Sonalde, Prem Vashishtha and Omkar Joshi (2015), Mahatma Gandhi National Rural Employment Guarantee Act: A Catalyst for Rural Transformation, New Delhi: National Council of Applied Economic Research.

Drèze, Jean (2017), “Universal Basic Income for India Suddenly Trendy. Look Out." Blog Post, NDTV.

Drèze, Jean and Reetika Khera (2011), "Employment Guarantee and the Right to Work," in Reetika Khera (ed.) The Battle for Employment Guarantee, New Delhi: Oxford University Press.

Dutta, Puja, Rinku Murgai, Martin Ravallion and Dominique van de Walle (2012), "Does India's Employment Guarantee Scheme Guarantee Employment?" Economic and Political Weekly 48 (April 21): 55-64.

and (2014), Right to Work? Assessing India's Employment Guarantee Scheme in Bihar. Washington DC: World Bank.

Fiszbein, Ariel, and Norbert Schady (2010), Conditional Cash Transfers for Attacking Present and Future Poverty, World Bank, Washington DC.

Fleischacker, Samuel (2004), A Short History of Distributive Justice. Cambridge MA: Harvard University Press.

Friedman, Milton (1962), Capital and Freedom, University of Chicago Press, Chicago.

Gaiha, Raghav (1997), "Rural Public Works and the Poor: The Case of the Employment

Guarantee Scheme in India," in S. Polachek (ed.) Research in Labour Economics, Connecticut: JAI Press.

Gatenio Gabel, Shirley (2016), A Right-Based Approach to Social Policy Analysis, Springer.

Gibson, John, Geua Boe-Gibson, Halahingano Rohorua and David McKenzie (2014), "Efficient Remittance Services for Development in the Pacific," Asia-Pacific Development Journal 14(2): 55-74.

Gelbach, Jonah, and Lant Pritchett (2000), "Indicator Targeting in a Political Economy: Leakier can be Better." Journal of Policy Reform 4: 113-45.

Government of India (GOI) (2017), Economic Survey 2016-17, Ministry of Finance, Government of India.

Government of India. (2018), Economic Survey 2017-18, Ministry of Finance, 
Grosh, Margaret (1994), Administering Targeted Social Programs in Latin America: From Platitudes to Practice. Washington DC: World Bank.

Gupta, Alok (2013), "Millionaire Mukhiyas," Blog Post, Down to Earth.

Haushofer, Johannes, and Jeremy Shapiro (2018), "The Long-Term Impact of Unconditional Cash Transfers: Experimental Evidence from Kenya," Busara Center for Behavioral Economics, Nairobi, Kenya.

The Hindi (2018), “99\% of MGREGA Wages Remain Unpaid,” April 12.

Imbert, Clement and John Papp (2011), "Estimating Leakages in India's Employment Guarantee," in Reetika Khera (ed.) The Battle for Employment Guarantee, New Delhi: Oxford University Press. , and (2015), "Labor Market Effects of Social Programs: Evidence from India's Employment Guarantee." American Economic Journal: Applied Economics 7(2): 233-263.

International Labor Organization (2012), "R202:Social Protection Floors Recommendation," Recommendation concerning National Floors of Social Protection Adoption, Geneva, 101st ILC session.

International Monetary Fund (IMF) (2017), IMF Fiscal Monitor: Tackling Inequality, Fiscal Affairs Department IMF, Washington DC.

Jack, William, Adam Ray, and Tavneet Suri (2013), “Transaction Networks: Evidence from Mobile Money in Kenya," American Economic Review Papers and Proceedings 103(3): 356-61.

Jalan, Jyotsna and Martin Ravallion (2003), "Estimating the Benefit Incidence of an AntiPoverty Program by Propensity-Score Matching", Journal of Business and Economic Statistics 21(1): 19-30.

Jha, Raghbendra, Sambit Bhattacharyya, Raghav Gaiha and Shylashri Shankar (2009), "'Capture' of Anti-Poverty Programs: An Analysis of the National Rural Employment Guarantee Program in India," Journal of Asian Economics 20(4): 456-464.

Jha, Raghbendra, Raghav Gaiha, Manoj K. Pandey (2012), "Net Transfer Benefits under India's Rural Employment Guarantee Scheme," Journal of Policy Modeling 34(2): 296-311.

Jones, Damon and Ioana Marinescu (2017), "The Labor Market Impacts of Universal and Permanent Cash Transfers: Evidence from the Alaska Permanent Fund.” Working paper.

Joshi, Vijay (2016), India's Long Road: The Search for Prosperity, Penguin Books India.

Kanbur, Ravi, Michael Keen, and Matti Tuomala (1994), "Labor Supply and Targeting in Poverty Alleviation Programs," World Bank Economic Review 8(2): 191-211.

Kautilya (undated), Arthashastra, R. Shamasastry's translation. Bangalore: Government Press. Khosla, Saksham (2017), "India's Universal Basic Income: Bedeviled by Details," Carnegie India.

Korpi, Walter, and Joakim Palme (1998), "The Paradox of Redistribution and Strategies of Equality: Welfare State Institutions, Inequality and Poverty in Western Countries," American Sociological Review October.

Lowrie, Annie (2017), “The Future of not Working," New York Times Feb. 23.

Mansuri, Ghazala, and Vijayendra Rao (2012), Localizing Development: Does Participation Work? Washington DC: World Bank.

Marinescu, Ioana (2018), "No Strings Attached: The Behavioral Effects of U.S. Unconditional Cash Transfer Programs,” NBER Working Paper 24337. 
Moffitt, Robert (1992), "Incentive Effects of the US Welfare System: A Review," Journal of Economic Literature 30(1): 1-61.

Muralidharan, Karthik, Paul Niehaus, and Sandip Sukhtankar (2018), “General Equilibrium Effects of (Improving) Public Employment Programs: Experimental Evidence from India," University of California, San Diago.

Murgai, Rinku, Martin Ravallion and Dominique van de Walle (2016), "Is Workfare Cost Effective against Poverty in a Poor Labor-Surplus Economy?”, World Bank Economic Review, 30(3):413-445.

Murray, Charles (2016), “A Guaranteed Income for Every American," Wall Street Journal June 2.

Myers-Lipton, Scott (2015), Ending Extreme Inequality: An Economic Bill of Rights to Eliminate Poverty. London and New York: Routledge.

Narayan, Deepa, Lant Pritchett and Soumya Kapoor (2009), Moving Out of Poverty. Success from the Bottom Up. Washington DC: World Bank.

Narayanan, Sudha, Krushna Ranaware, Upasak Das and Ashwini Kulkarni (2015), "MGNREGA Works and their Impact: A Study of Maharashtra," Economic and Political Weekly 50(13): 53-61.

Ozler, Berk (2017), "Fact Checking Universal Basic Income: Can we Transfer our Way out of Poverty?" Blog Post, Development Impact, World Bank.

Paine, Thomas (1797), Agrarian Justice, 2004 edition published with Common Sense by Penguin. Paul, Mark, William Darity Jr., and Darrick Hamilton (2017), "Why we Need a Federal Job Guarantee," Jacobin.

Ravallion, Martin (1990), "Anti-Hunger Policies in Market Economies: Effects on Wages, Prices and Employment", in Jean Drèze and Amartya Sen (eds), The Political Economy of Hunger, Oxford University Press, Oxford.

(1991), "Reaching the Rural Poor through Public Employment: Arguments, Experience and Lessons from South Asia," World Bank Research Observer 6: 153-175. (1994), Poverty Comparisons, Chur, Switzerland: Harwood Academic Press. (1999), “Appraising Workfare,” World Bank Research Observer 14: 31-48. (2009), "How Relevant is Targeting to the Success of the Antipoverty Program?" World Bank Research Observer 24(3): 205-231. (2016a), The Economics of Poverty: History, Measurement and Policy, Oxford University Press, Oxford and New York. (2016b), "Are the World's Poorest Being Left Behind?," Journal of Economic Growth 21(2):139-164. (2017a), Interventions against Poverty in Poor Places, WIDER Annual Lecture, World Institute of Development Economics, Helsinki. (2017b), "Inequality and Poverty when Effort Matters," Econometrics 5(4). (2017c), "Straw Men in the Debate on Basic Income versus Targeting,"

Blog post, VoxDev.

Ravallion, Martin, and Shaohua Chen (2015). 'Benefit Incidence with Incentive Effects, Measurement Errors and Latent Heterogeneity: A Case Study for China', Journal of Public Economics 128: 124-32. 
Ravallion, Martin, and Gaurav Datt (1995), 'Is Targeting Through a Work Requirement Efficient? Some Evidence for Rural India', in Dominique de Walle, and Kimberly Nead (eds) Public Spending and the Poor: Theory and Evidence. Baltimore: Johns Hopkins University Press.

Ravallion, Martin, Gaurav Datt, and Shubham Chaudhuri (1993), "Does Maharashtra's 'Employment Guarantee Scheme' Guarantee Employment? Effects of the 1988 Wage Increase," Economic Development and Cultural Change 41: 251-75.

Ravallion, Martin, Emanela Galasso, Teodoro Lazo and Ernesto Philipp (2005), "What Can Ex-participants Reveal about a Program's Impact?” Journal of Human Resources 40: 208230.

Ravallion, Martin, Dominique van de Walle, Puja Dutta, and Rinku Murgai (2015), "Empowering Poor People through Public Information? Lessons from a Movie in Rural India," Journal of Public Economics 132: 13-22.

Ravi, Shamika, and Monika Engler (2015), "Workfare as an Effective Way to Fight Poverty: The Case of India's NREGA," World Development 67: 57-71.

Sandefur, Justin (2017), "Disintermediating the State: Would a Universal Basic Income Reduce Poverty more than Targeted Programs?” Blog Post, Center for Global Development, Washington DC.

Sen, Amartya (1995), “The Political Economy of Targeting”, in D van de Walle and K Nead (eds.), Public Spending and the Poor, Johns Hopkins University Press.

Silver, Hilary (1994), "Social Exclusion and Social Solidarity," International Labour Review 133(5-6): 531-78.

Solar, Peter (1995), "Poor Relief and English Economic Development before the Industrial Revolution," Economic History Review 48: 1-22.

Standing, Guy (2005), "Why Basic Income is Needed for a Right to Work," Journal of Law and Urban Policy 2: 91-102.

United Nations (UN) (2006), Right to Work: Article 6 of the International Covenant on Economic, Social and Cultural Rights, Economic and Social Council, United Nations.

van de Walle, Dominique (1998), “Targeting Revisited," World Bank Research Observer, 13(2): 231-48.

Van Parijs, Philippe (1995), Real Freedom for All: What (if anything) can Justify Capitalism? Oxford: Oxford University Press.

Van Parijs, Philippe and Yannick Vanederborght (2017), Basic Income: A Radical Proposal for a Free Society. Cambridge MA: Harvard University Press.

Verma, Shilp (2011), MGNREGA Assets and Rural Water Security: Synthesis of Field Studies in Bihar, Gujarat, Kerala and Rajasthan, Anand: International Water Management Institute (IWMI).

Walker, Robert (2014), The Shame of Poverty, Oxford: Oxford University Press.

Witsoe, Jeffrey (2012), "Everyday Corruption and the Political Mediation of the Indian State," Economic and Political Weekly 47(6): 47-54.

World Bank (2011), Poverty and Social Exclusion in India, Washington DC: World Bank.

Zimmerman, Laura (2013), "Why Guarantee Employment? Evidence from a Large Indian Public Works Program," University of Michigan, Ann Arbor, Michigan. 


\section{Appendix}

\section{Endogenous rationing in an employment guarantee scheme}

To provide a more formal exposition of the argument in Section 3, consider the following model. It simplifies the exposition to start with the case in which there is no corruption, and then introduce this feature.

The central government requests the local government to provide work for all those who want it at the stipulated wage rate. The central government pays the un-skilled labor cost (and possibly some other costs). The local official still incurs a cost, and chooses the level of employment $E$ to minimize a generalized cost function subject to the constraint that people cannot be forced to work. (All functions are twice differentiable when required.) The demand for work, $D$, is taken as given by the official. The average rationing rate is $1-E / D$ while the marginal rate is $1-$ $\partial E / \partial D$.

The local official's problem is to choose $E$ to solve:

$$
\operatorname{Min} c E+p(D-E) \text { s.t. } E \leq D
$$

where $c$ is the unit cost and the function $p($.$) penalizes the unmet demand for work. It$ is assumed that the penalty function is strictly increasing and convex with $p(0)=0$. Let $E^{*}$ denote the level of employment such that:

$$
p^{\prime}\left(D-E^{*}\right)=c
$$

Inverting (2) we have:

$$
E^{*}=D-f(c)
$$

where $f($.$) is the inverse function of p^{\prime}($.$) . The value of f(c)$ gives the minimum level of demand for work before the government will begin to hire any workers. It is readily verified that $f(c)>0$ and $f^{\prime}(c)=1 / p^{\prime \prime}(c)>0$. If there is rationing in equilibrium then it will be in the amount $f(c)$. Above this, the marginal rate of rationing is zero (though that will change when corruption is introduced).

The local government may comply with the center's request to guarantee employment even though the local government incurs a share of the cost. But the share cannot exceed a critical value. One can distinguish two regimes: In $\underline{\text { Regime } 1}$ we have: 


$$
c \leq c^{*} \equiv p(f(c)) / f(c)
$$

Then the local government official will choose to comply with the central dictate to employ all those who want work, noting that (4) implies that the cost of compliance, c.D, is no greater than the minimum cost of rationing, $c E^{*}+p\left(D-E^{*}\right)$.

By contrast, in $\underline{\text { Regime } 2}, c>c^{*}$. Then the unit cost facing the local official is sufficiently high for rationing to emerge in equilibrium, in that the cost of employing $E^{*}$ workers is less than the cost of employing all those who want work. Then $E^{*}$ is the official's optimal level of employment to be provided and there will be unmet demand in equilibrium, in that $E^{*}<D$ with $f(c)$ workers rationed. A reduction in the unit cost will increase employment and reduce the overall rationing rate.

Now introduce corruption into this model. The official can extract an illegal "rent" of $r$ per worker employed, but the official faces an expected cost of corruption of $C(E)$; this cost function is taken to be strictly increasing and convex (for the reasons given in Section 3). The problem facing the local official is now:

$$
\operatorname{Max}(r-c) E-C(E)-p(D-E) \text { s.t. } E \leq D
$$

There can be unmet demand in equilibrium if $E^{*}<D$, where $E^{*}$ now solves:

$$
r=C^{\prime}\left(E^{*}\right)+c-p^{\prime}\left(D-E^{*}\right)
$$

This is illustrated in Figure 3 where $M B \equiv r$ and $M C \equiv C^{\prime}(E)+c-p^{\prime}(D-E)$. Notice that, with this addition to the model, there will now be rationing at the margin, since:

$$
0<\frac{\partial E^{*}}{\partial D}=\frac{1}{1+C^{\prime \prime}(.) / p^{\prime \prime}(.)}<1
$$

Also note that a reform that simultaneously shifted up $C^{\prime}(E)$ while reducing $c$ by the same amount would leave $E^{*}$ unchanged. 


\section{Figures}

Figure 1: Incidence of rationing in India's Employment Guarantee Scheme plotted against the poverty rate across states.

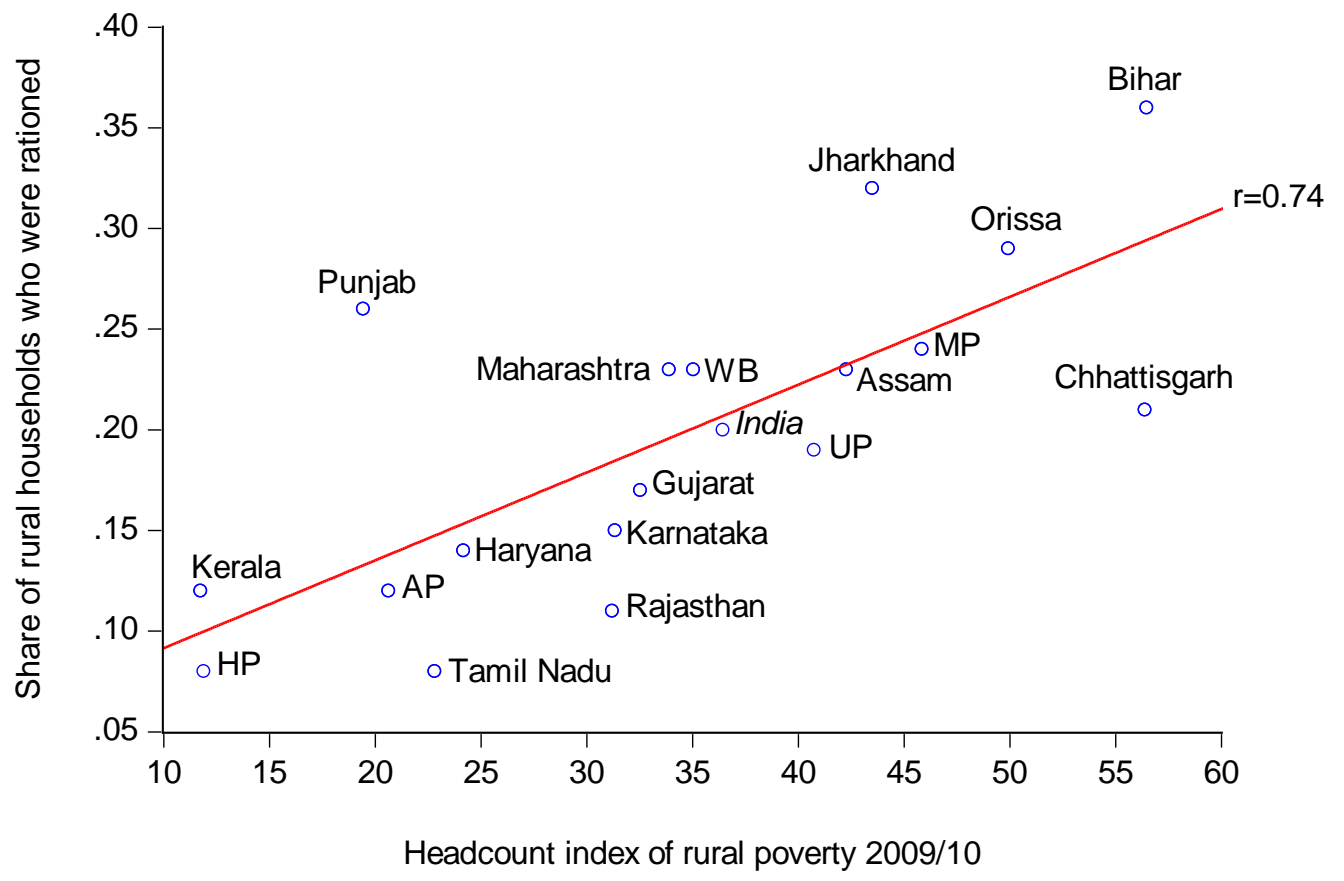

Source: India's National Sample Survey 2010.

$\mathrm{AP}=$ Andhra Pradesh; HP=Himachal Pradesh; MP=Madhya Pradesh; UP=Uttar Pradesh; WB=West Bengal 
Figure 2: There is less sign that workfare jobs are rationed at the margin than on average in India's National Employment Guarantee Scheme

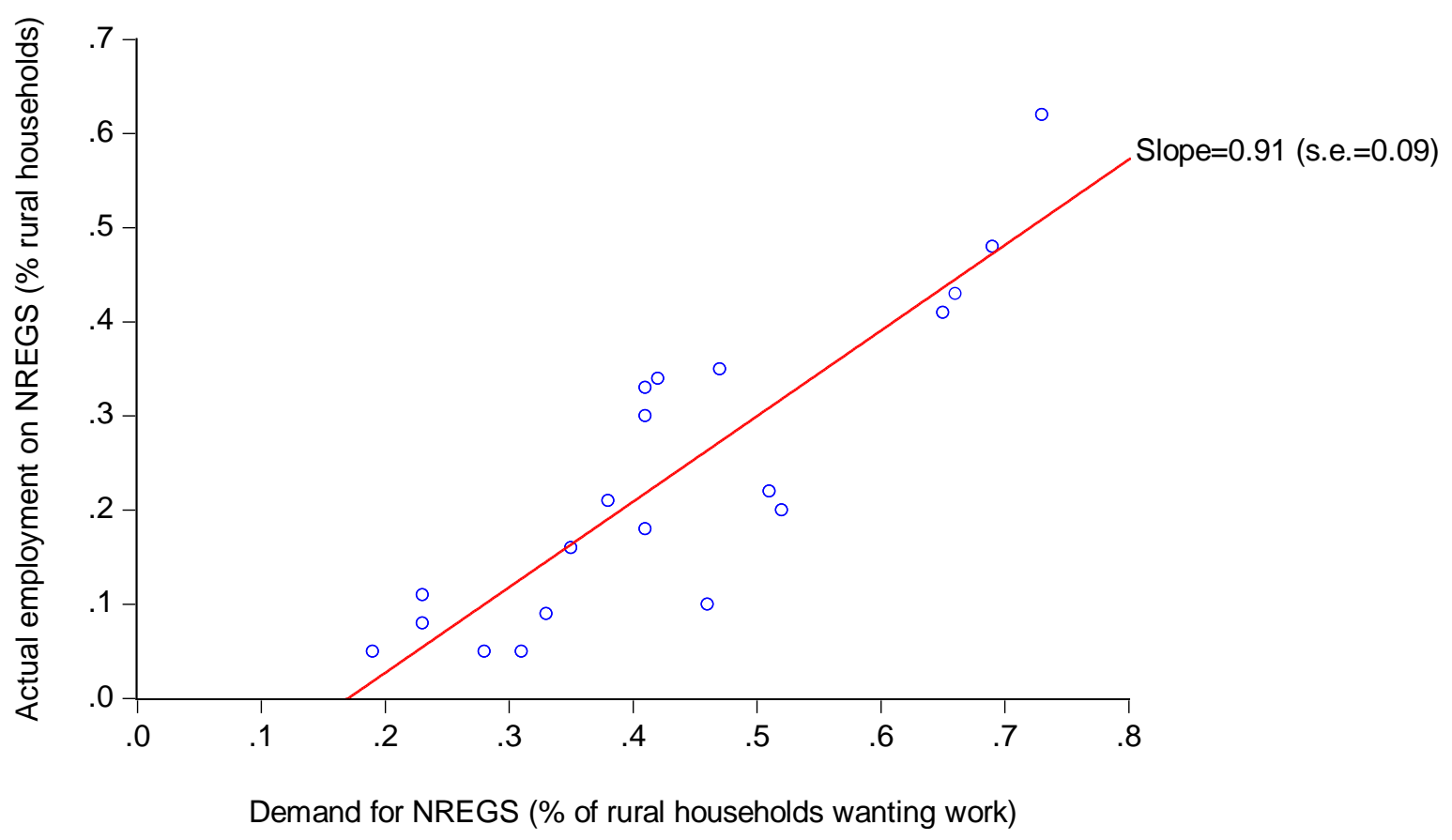

Source: India’s National Sample Survey 2010, via Dutta et al. (2014).

Figure 3: Local officials facing a steeply increasing marginal cost of corruption

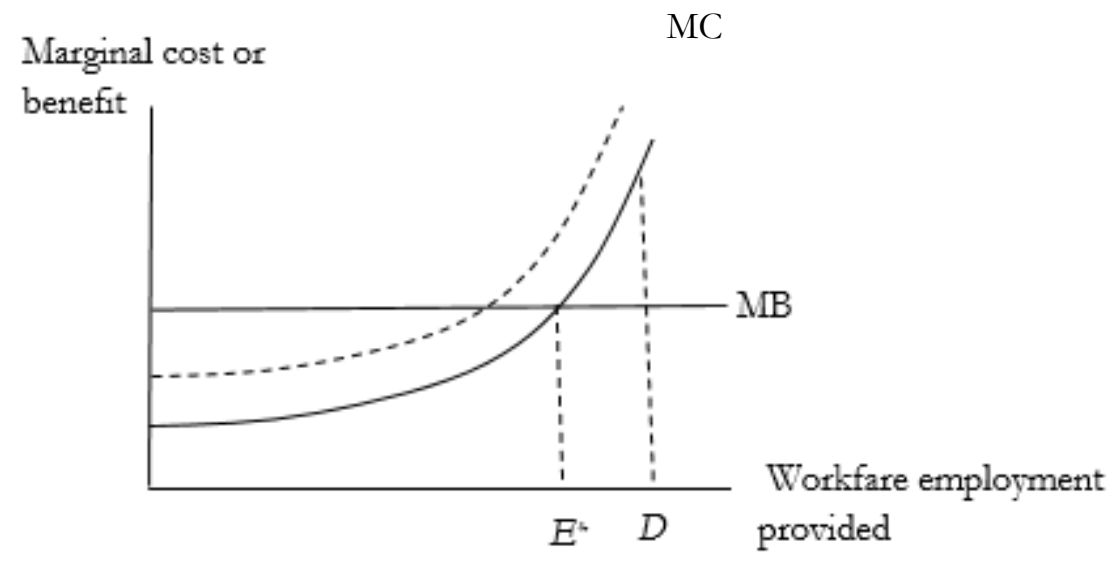

